Article

\title{
Design and Implementation of a STATCOM Based on a Multilevel FHB Converter with Delta-Connected Configuration for Unbalanced Load Compensation
}

\author{
Wei-Neng Chang ${ }^{1, *}$ and Ching-Huan Liao ${ }^{2}$ \\ 1 Department of Electrical Engineering, Chang Gung University, 259 Wen-Hwa 1st Road, Kwei-Shan Dist., \\ 333 Tao-Yuan City, Taiwan \\ 2 National Chung-Shan Institute of Science and Technology, 486, 6th Neighborhood, Sec. Jia'an, \\ Zhongzheng Road, Longtan Dist., 325 Tao-Yuan City, Taiwan; howardliao05@gmail.com \\ * Correspondence: nchang@mail.cgu.edt.tw; Tel.: +886-3-211-8800
}

Received: 9 January 2017; Accepted: 28 June 2017; Published: 4 July 2017

\begin{abstract}
A delta-connected STATCOM with cascade multilevel full H-bridge (FHB) converter has been applied for phase balancing and power factor correction of unbalanced load in a three-phase, three-wire power distribution system. In this paper, a feedforward compensation formula is presented for the STATCOM by using the symmetrical components method to compensate unbalanced load. Computer simulation is performed for preliminary verification. Accordingly, a hardware prototype employing a TMS320F2812 DSP-based system is built for final verification test. Experimental results show that the proposed STATCOM is very effective for real-time unbalanced load compensation.
\end{abstract}

Keywords: FHB; hardware test; load compensation; STATCOM; symmetrical components method

\section{Introduction}

A large unbalanced capacity load, such as a single-phase electrical railway system, in a three-phase, three-wire electric power distribution system can absorb undesired negative-sequence currents and reactive power. The negative-sequence current and reactive power cause additional losses in the power distribution system and produce an unbalanced voltage drop on the distribution line, which should be improved to ensure satisfactory power quality. Voltage fluctuations caused by large inductive loads such as electric arc furnace can induce light flicker. Therefore, unbalanced load compensation, including phase balancing and power factor correction, is very important in electric power distribution systems.

Thyristor-controlled reactor with thyristor-switched capacitor (TCR-TSC) type static var compensators (SVCs) with delta-connected configuration and individual-phase control are applied in power distribution systems for real-time unbalanced load compensation and voltage regulation [1-6]. In recent years, the static synchronous compensator (STATCOM) has been recognized as the next-generation compensator [7-10]. Properly designed STATCOMs can be used for real-time unbalanced load compensation. Compared to SVCs, STATCOMs have compact structures, faster response times, they demand less space, and generate lower noise. Many types of converter/inverter are employed to construct the main circuit of a STATCOM, such as cascade multilevel full H-bridge (FHB) converter, diode-clamped converter, and flying-capacitor converter [11-14]. Among them, the STATCOM using cascade multilevel FHB converter as main circuit has the advantages of a modular structure and ease of redundant operation, which is suitable for high-voltage and high-power applications.

STATCOMs using cascade multilevel full $\mathrm{H}$-bridge (FHB) converters can be connected in a $\mathrm{Y}$ configuration [15-19], which is also known as a single-star bridge-cells (SSBCs)-based STATCOM [20]. The SSBCs-based STATCOM can provide reactive power compensation and voltage support in balance 
operations. However, using the SSBCs-based STATCOM to compensate unbalanced load causes voltage shifting at neutral point of main circuit, which is not suitable for unbalanced load compensation [20,21]. Cascade FHBs-based STATCOM can also be connected as a delta configuration [22-29]. This type of STATCOM is also known as single delta bridge cells (SDBCs)-based STATCOM, which not only can compensate the negative-sequence current of unbalanced loads to achieve a balanced operation, but also perform unity power factor correction. In [26], a delta-connected STATCOM with multilevel optimal modulation strategy is proposed to reduce harmonic distortion. Furthermore, using a special switching patterns swapping maintains dc-link voltages in balanced operation. However, the delta-connected STATCOM is only used in balanced operation. A control method based on instantaneous power theory for SDBCs-based STATCOM is employed to compensate positive-sequence and negative-sequence reactive powers in [28]. In [29], a hybrid multilevel FHB based, delta-connected STATCOM is proposed, which synthesizes voltage waveforms by using two modulation frequencies. In each STATCOM arm, the high-voltage FHB cell uses step modulation and the low-voltage FHB uses $5 \mathrm{kHz}$ pulse width modulation (PWM) technique at the same time. This modulation technique can not only improve efficiency and output waveform, but also compensate reactive power and negative-sequence currents. In [28-30], zero-sequence circulating current in the delta-connected main circuit of the SDBCs-based STATCOM is employed to construct the compensation current for unbalanced load compensation. However, all the above mentioned STATCOMs need complicated calculations and high frequency PWM techniques. The use of PWM techniques in the STATCOMs reduces the main circuit efficiency, which is not suitable for STATCOMs in high power application if they want to compete with the existing SVCs in the industry. In [25], a current-regulated DSTATCOM based on cascade multilevel FHB converter is proposed for unbalanced load compensation. Use of reactive parts of load currents calculates the compensation currents.

In this paper, a delta-connected, transformerless STATCOM with cascade multilevel FHB converter and step modulation is introduced for real-time unbalanced load compensation in three-phase, three-wire distribution systems. A systematic design approach regarding the load demand, the sizing of the STATCOM, and the power source response is proposed. To meet the fast response requirements, a feedforward compensation formula is derived for the STATCOM. Use of step modulation in the STATCOM main circuit achieves high efficiency operation. The MatLab/Simulink program is used in simulation for preliminary verification. A hardware prototype is built for a final verification test. Experimental results are presented for functioning verification. This paper introduces a very suitable transition of technology from existing SVC to new-generation STATCOM in high power application.

\section{Operation of the STATCOM Main Circuit}

Figure 1 shows the studied system, which is a three-phase power distribution system with unbalanced load and the proposed transformerless, delta-connected STATCOM. In Figure 1a, a cascade 7-level FHB converter is used to construct the STATCOM main circuit arms. Individual phase control of the three STATCOM arms is available for unbalanced load compensation like a traditional SVC. Each arm of the STATCOM consists of three FHB cells and a reactor $X^{S T}$ connected in series. Every FHB cell in each STATCOM arm has its own dc-link capacitor.

Mostly, STATCOMs are controlled on the synchronous $q$ - $d$ reference frame. The dc-link voltage of the STATCOM is controlled on the $d$-axis. At the same time, the reactive power or current is regulated on the $q$-axis $[11-17,26,28]$. This control scheme can be implemented by using PWM techniques, but the power efficiency is sacrificed, which is not suitable for high power applications. Another control scheme is to directly regulate the STATCOM internal angle for reactive power control, which achieves high efficiency operation [31]. Hence, this paper uses the internal phase angle control for the STATCOM. The STATCOM controller regulates the internal phase angle $\delta^{S T}$ for different reactive power demands. In this paper, the STATCOM is equivalent as reactive power load like an SVC. The realization and operation of the STATCOM will be easy to field engineers. 
Equations (1) and (2) express the active and reactive power inputs of each STATCOM arm in Figure 1a. In steady state, the internal angle $\delta^{S T}$ is nearly kept at zero. For the need of capacitive reactive power, the STATCOM controller regulates the internal angle $\delta^{S T}$ to a negative value to absorb active power according to Equation (1), which charges the capacitors in the dc-links and boosts their voltages equally. When the dc-link voltages increase, the synthesized STATCOM internal voltage $V^{S T}$ rises. The STATCOM absorbs capacitive reactive power with the regulation according to Equation (2). When the reactive power input reaches the desired value, the internal angle goes back to near zero:

$$
\begin{gathered}
P^{S T}=-\frac{V^{S T} V^{L}}{X^{S T}} \sin \delta^{S T} \cong-\frac{V^{S T} V^{L}}{X^{S T}} \delta^{S T} \\
Q^{S T}=\frac{V^{L}\left(V^{L}-V^{S T} \cos \delta^{S T}\right)}{X^{S T}} \cong \frac{V^{L}\left(V^{L}-V^{S T}\right)}{X^{S T}}
\end{gathered}
$$

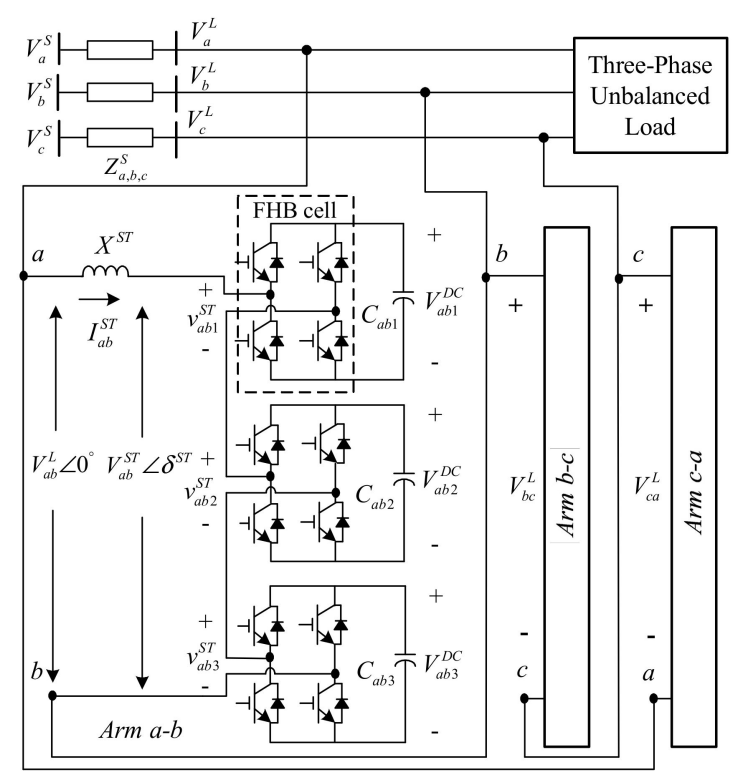

(a)

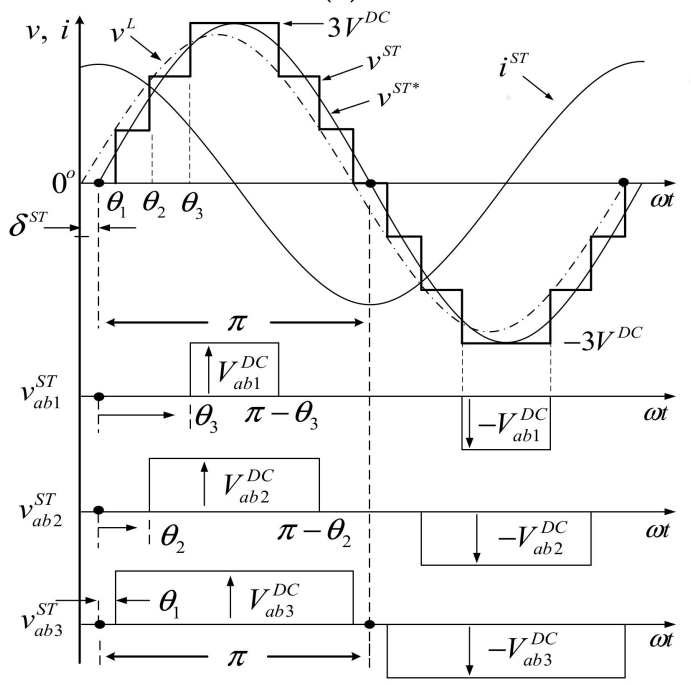

(b)

Figure 1. The studied system (a) three-phase unbalanced load and the proposed STATCOM; (b) Current and voltage waveforms of the STATCOM arm $a-b$ (charging mode, $\delta^{S T}<0$ ). 
Figure $1 \mathrm{~b}$ shows the current and voltage waveforms of the STATCOM arm a-b in Figure $1 \mathrm{a}$. With the control of the switching angles, $\theta_{1}, \theta_{2}$, and $\theta_{3}$, each FHB cell generates three output voltages, $+V^{D C}, 0$, and $-V^{D C}$, which synthesize the STATCOM internal voltage $v^{S T}\left(v_{S}^{T}=v_{a b 1}^{S T}+v_{a b 2}^{S T}+v_{a b 3}^{S T}\right)$ as a stepped waveform. The STATCOM controller dynamically regulates the internal angle $\delta^{S T}$ for obtaining the needed reactive power input. The switching angles, $\theta_{1}, \theta_{2}$, and $\theta_{3}$, should be properly selected for minimizing the harmonics generated.

The internal voltage waveform $v^{S T}$ in Figure $1 \mathrm{~b}$ can be represented as a Fourier series, as shown in Equation (3):

$$
v^{S T}(\omega t)=\frac{4 V^{D C}}{\pi} \sum_{n}\left[\cos \left(n \theta_{1}\right)+\cos \left(n \theta_{2}\right)+\cos \left(n \theta_{3}\right)\right] \frac{\sin (n \omega t)}{n}
$$

In Equation (3), $n$ is the harmonic order of $v^{S T}$, where $n=1,3,5,7, \ldots$ Ideally, the harmonic orders contain only odd orders without even order harmonic component. The amplitude of each harmonic component in Equation (3) can further be represented in Equation (4):

$$
H^{S T}(n)=\frac{4 V^{D C}}{n \pi}\left[\cos \left(n \theta_{1}\right)+\cos \left(n \theta_{2}\right)+\cos \left(n \theta_{3}\right)\right], n=1,3,5,7, \ldots
$$

To produce the needed fundamental component and eliminate undesired harmonics, a harmonic minimizing method is employed [32,33]. In Equation (4), taking $n=1$ obtains the fundamental component of the internal voltage waveform, $H^{S T}(1)=4 V^{D C}\left[\cos \theta_{1}+\cos \theta_{2}+\cos \theta_{3}\right] / \pi$, which consists of dc-link voltage $\left(V^{D C}\right)$ and three switching angles $\left(\theta_{1}, \theta_{2}, \theta_{3}\right)$. Assigning $H^{S T}(1)=3 V^{D C}$ obtains $\cos \left(\theta_{1}\right)+\cos \left(\theta_{2}\right)+\cos \left(\theta_{3}\right)=3 \pi / 4$. For a delta-connected STATCOM in balanced operation, the harmonic currents of triple order (zero sequence) will circulate in the main circuit of the STATCOM. Careful choice of the switching angles can eliminate the non-triple order harmonic currents. The undesired fifth and seventh order harmonic components are set at zero in (4). From the above considerations, the three switching angles $\left(\theta_{1}, \theta_{2}, \theta_{3}\right)$ are obtained from Equation (5). Using the Newton-Raphson method to solve Equation (5) yields the switching angles, $\theta_{1}=11.68^{\circ}, \theta_{2}=31.18^{\circ}$, and $\theta_{3}=58.58^{\circ}$ :

$$
\begin{aligned}
& \cos \left(\theta_{1}\right)+\cos \left(\theta_{2}\right)+\cos \left(\theta_{3}\right)=3 \pi / 4 \\
& \cos \left(5 \theta_{1}\right)+\cos \left(5 \theta_{2}\right)+\cos \left(5 \theta_{3}\right)=0 \\
& \cos \left(7 \theta_{1}\right)+\cos \left(7 \theta_{2}\right)+\cos \left(7 \theta_{3}\right)=0 \\
& \text { where : } 0<\theta_{1}<\theta_{2}<\theta_{3}<\pi / 2
\end{aligned}
$$

\section{STATCOM Compensation Formula and Controller}

\subsection{The Proposed Compensation Formula}

Figure 2 shows the studied system for deriving the feedforward compensation formula. The studied system is a three-phase, three-wire electric power distribution system feeding an unbalanced inductive load. The STATCOM executes the on-site load compensation. The steady-state symmetrical components method has been widely used for deriving SVCs' real-time unbalanced load compensation schemes [2-4]. In the paper, the method is employed for deriving the needed feedforward compensation formula for the STATCOM. The feedforward compensation formula detects the load power parameters and sends three reactive power control commands to the STATCOM main circuit arms. With the commands, the three STATCOM arms regulate their reactive power inputs, independently. As a result, the synthesized STATCOM line current compensates the imaginary part of positive-sequence component and overall negative-sequence component of the load current. Hence, the three-phase source currents are compensated to be balanced and unity power factor. 
In Figure 2, the line-to-line voltages of the load bus are assumed to be balanced, as shown in Equation (6). In Equation (6), $V^{L}$ is the effective (rms) value of the line-to-line voltage. Equation (7) gives the three-arm currents of the STATCOM, in which the relationship of $V^{*} I=P-j Q$ is used.

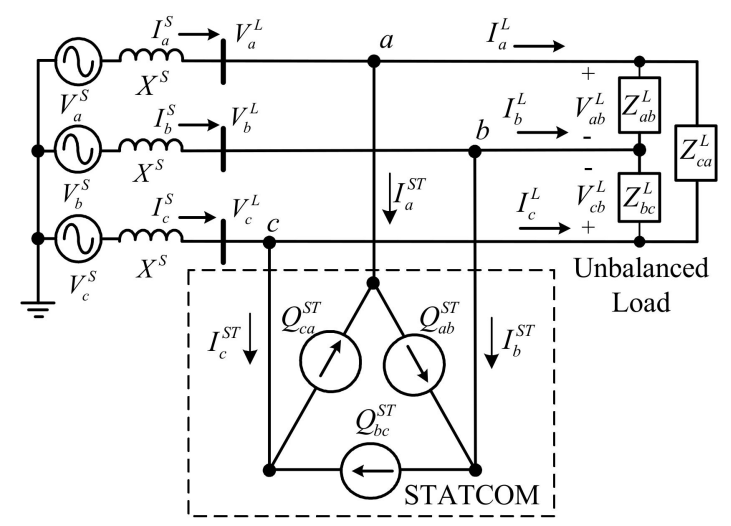

Figure 2. Three-phase, three-wire unbalanced load and the STATCOM.

$$
\begin{aligned}
\bar{V}_{a b}^{L} & =\bar{V}_{a}^{L}-\bar{V}_{b}^{L}=V^{L} \angle 30^{\circ} \\
\bar{V}_{b c}^{L} & =\bar{V}_{b}^{L}-\bar{V}_{c}^{L}=V^{L} \angle-90^{\circ} \\
\bar{V}_{c a}^{L} & =\bar{V}_{c}^{L}-\bar{V}_{a}^{L}=V^{L} \angle 150^{\circ} \\
\bar{I}_{a b}^{S T} & =\left(-j Q_{a b}^{S T}\right) /\left(V^{L} \angle-30^{\circ}\right) \\
\bar{I}_{b c}^{S T} & =\left(-j Q_{b c}^{S T}\right) /\left(V^{L} \angle 90^{\circ}\right) \\
\bar{I}_{c a}^{S T} & =\left(-j Q_{c a}^{S T}\right) /\left(V^{L} \angle-150^{\circ}\right)
\end{aligned}
$$

The synthesized line currents of the STATCOM are calculated by using Equation (8). Use of the symmetrical components transformation in Equation (9) obtains the symmetrical components of the STATCOM line current in terms of reactive power inputs of the three STATCOM arms, as shown in Equation (10). Equation (10) is the rectangular form of Equation (9). For a delta-connected STATCOM, the zero-sequence component in Equation (9) is zero:

$$
\begin{aligned}
& {\left[\begin{array}{c}
\bar{I}_{a}^{S T} \\
\bar{I}_{b}^{S T} \\
\bar{I}_{c}^{S T}
\end{array}\right]=\left[\begin{array}{c}
\bar{I}_{a b}^{S T}-\bar{I}_{c a}^{S T} \\
\bar{I}_{b c}^{S T}-\bar{I}_{a b}^{S T} \\
\bar{I}_{c a}^{S T}-\bar{I}_{b c}^{S T}
\end{array}\right]}
\end{aligned}
$$

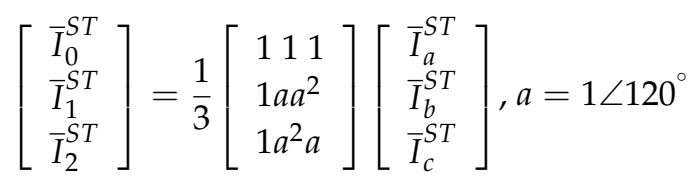

$$
\begin{aligned}
& \bar{I}_{1}^{S T}=\frac{-j}{3 V^{L}}\left(Q_{a b}^{S T}+Q_{b c}^{S T}+Q_{c a}^{S T}\right) \\
& \left.\bar{I}_{2}^{S T}=\frac{1}{3 V^{L}} \angle-30^{\circ} Q_{a b}^{S T}+a Q_{b c}^{S T}+a^{2} Q_{c a}^{S T}\right) \\
& =\frac{1}{\sqrt{3} \mathrm{~V}^{L}}\left[\left(\frac{\sqrt{3}}{2} Q_{a b}^{S T}-\frac{\sqrt{3}}{2} Q_{c a}^{S T}\right)+j\left(\frac{-1}{2} Q_{a b}^{S T}+Q_{b c}^{S T}-\frac{1}{2} Q_{c a}^{S T}\right)\right]
\end{aligned}
$$


Use of the two-wattmeter method for the unbalanced load obtains the symmetrical components of the load current. Equation (11) is the line-to-line powers flowing to the load. From Equation (11), the symmetrical components of the load current are shown in Equation (12):

$$
\begin{gathered}
\left(\bar{V}_{a b}^{L}\right)\left(\bar{I}_{a}^{L}\right)^{*}=V^{L} \angle 30^{\circ}\left[\left(\bar{I}_{1}^{L}\right)^{*}+\left(\bar{I}_{2}^{L}\right)^{*}\right] \\
\left(\bar{V}_{c b}^{L}\right)\left(\bar{I}_{c}^{L}\right)^{*}=-a^{2} V^{L} \angle 30^{\circ}\left[a^{2}\left(\bar{I}_{1}^{L}\right)^{*}+a\left(\bar{I}_{2}^{L}\right)^{*}\right] \\
{\left[\begin{array}{c}
\bar{I}_{1}^{L} \\
\bar{I}_{2}^{L}
\end{array}\right]=\frac{-1}{\sqrt{3} V^{L}}\left[\begin{array}{cc}
-1 & -1 \\
a^{2} & 1
\end{array}\right]\left[\begin{array}{c}
\left(\bar{V}_{a b}^{L}\right)^{*}\left(\bar{I}_{a}^{L}\right) \\
\left(\bar{V}_{c b}^{L}\right)^{*}\left(\bar{I}_{c}^{L}\right)
\end{array}\right]} \\
\text { where, } \begin{array}{r}
\left(\bar{V}_{a b}^{L}\right)^{*}\left(\bar{I}_{a}^{L}\right)=P_{a b}^{L}-j Q_{a b}^{L} \\
\left(\bar{V}_{c b}^{L}\right)^{*}\left(\bar{I}_{c}^{L}\right)=P_{c b}^{L}-j Q_{c b}^{L}
\end{array}
\end{gathered}
$$

From the two-wattmeter method, use of Equation (13) calculates the three-phase active and reactive powers to the load. The three-phase powers from the power source can be obtained by a similar calculation. The symmetrical components of the load current in Equation (12) are rearranged as a rectangular form, as shown in Equation (14). For unbalanced load compensation, the STATCOM should eliminate the imaginary part of the positive-sequence component and total negative-sequence component of the load current, as shown in Equation (15):

$$
\begin{gathered}
P_{3 \phi}^{L}=P_{a b}^{L}+P_{c b}^{L}, Q_{3 \phi}^{L}=Q_{a b}^{L}+Q_{c b}^{L} \\
\bar{I}_{1}^{L}=\frac{1}{\sqrt{3} V^{L}}\left[\left(P_{a b}^{L}+P_{c b}^{L}\right)-j\left(Q_{a b}^{L}+Q_{c b}^{L}\right)\right] \\
\bar{I}_{2}^{L}=\frac{1}{\sqrt{3} V^{L}}\left[\left(\frac{1}{2} P_{a b}^{L}-P_{c b}^{L}+\frac{\sqrt{3}}{2} Q_{a b}^{L}\right)+j\left(\frac{-1}{2} Q_{a b}^{L}+Q_{c b}^{L}+\frac{\sqrt{3}}{2} P_{a b}^{L}\right)\right] \\
\operatorname{Im}\left\{\bar{I}_{1}^{L}\right\}+\bar{I}_{1}^{S T}=0, \bar{I}_{2}^{L}+\bar{I}_{2}^{S T}=0
\end{gathered}
$$

Finally, combining Equations (10), (14) and (15) gives the needed reactive power of each STATCOM arm for real-time load compensation, as shown in Equation (16). The load compensation formula in Equation (16) is very compact and suitable for the delta-connected STATCOM. The sizing of the STATCOM is easy by using Equation (16). With only few power transducers, the compensation formula is implemented easily:

$$
\begin{aligned}
& Q_{a b}^{S T *}=-Q_{a b}^{L}+\frac{1}{\sqrt{3}} P_{c b}^{L} \\
& Q_{b c}^{S T *}=-Q_{c b}^{L}-\frac{1}{\sqrt{3}} P_{a b}^{L} \\
& Q_{c a}^{S T *}=\frac{1}{\sqrt{3}} P_{a b}^{L}-\frac{1}{\sqrt{3}} P_{c b}^{L}
\end{aligned}
$$

With the STATCOM compensation, the source current only contains real part of the positive-sequence load current, as shown in Equation (17). As a result, the source current is balanced with unity power factor, as shown in Equation (18). A systematic design approach regarding the load demand, the sizing of the STATCOM, and the power source response is completed by using Equations (13), (16) and (18):

$$
\begin{aligned}
& \bar{I}_{1}^{S}=\operatorname{Re}\left\{\bar{I}_{1}^{L}\right\}=\frac{P_{a b}^{L}+P_{c b}^{L}}{\sqrt{3} V^{L}} \angle 0^{\circ}, \bar{I}_{2}^{S}=\bar{I}_{0}^{S}=0
\end{aligned}
$$

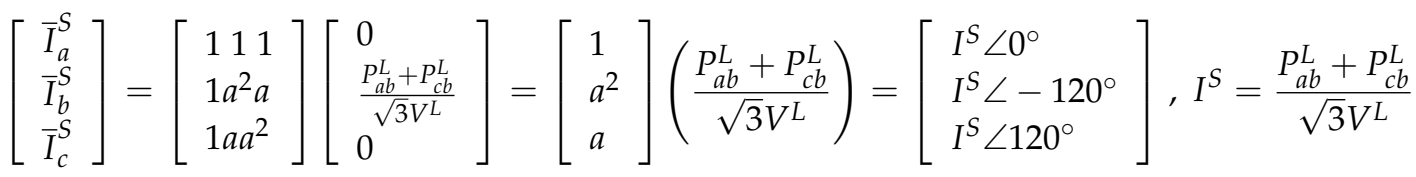




\subsection{The Proposed STATCOM Controller}

Figure 3a presents the architecture of the proposed STATCOM controller. Use of Equation (16) calculates the reactive power commands of the three STATCOM arms, $Q_{a b}^{S T *}, Q_{b c}^{S T *}$, and $Q_{c a}^{S T *}$, in real-time. First, the controller detects the line currents $\left(i_{a}^{L}, i_{c}^{L}\right)$ and line-to-line voltages $\left(v_{a b}^{L}, v_{c b}^{L}\right)$ of the unbalanced load to obtain the active and reactive powers $\left(P_{a b}^{L}, Q_{a b}^{L}, P_{c b}^{L}, Q_{c b}^{L}\right)$ to the load. A DSP-based power data detector is employed in the calculation. Three proportional-integral-derivative (PID) feedback controllers regulate the reactive power of the three STATCOM arms, independently. For example, the actual reactive power input $Q_{a b}^{S T}$ of the STATCOM arm $a-b$ is detected and then compared with the needed reactive power $Q_{a b}^{S T *}$. With the compared result, the PID controller generates the internal angle command $\delta_{a b}^{S T *}$. For prevention of over-current operation during system faults, internal angle limiters are installed in the outputs of the PID controllers. Finally, the internal angle command $\delta_{a b}^{S T *}$ produces the switching signals for the FHB cells according to Figure $1 \mathrm{~b}$. Three phase-locked loops (PLLs) generate reference signals for synchronizing switching patterns to FHB cells of each STATCOM arm, respectively.

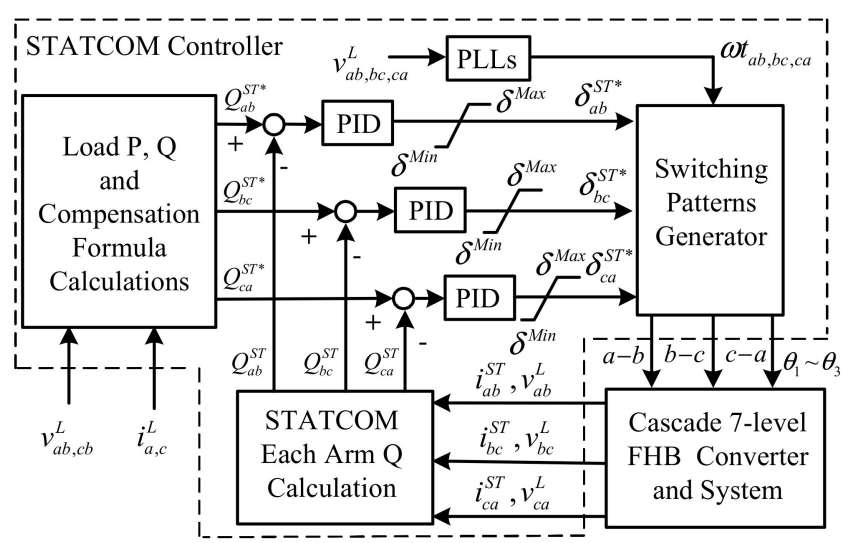

(a)

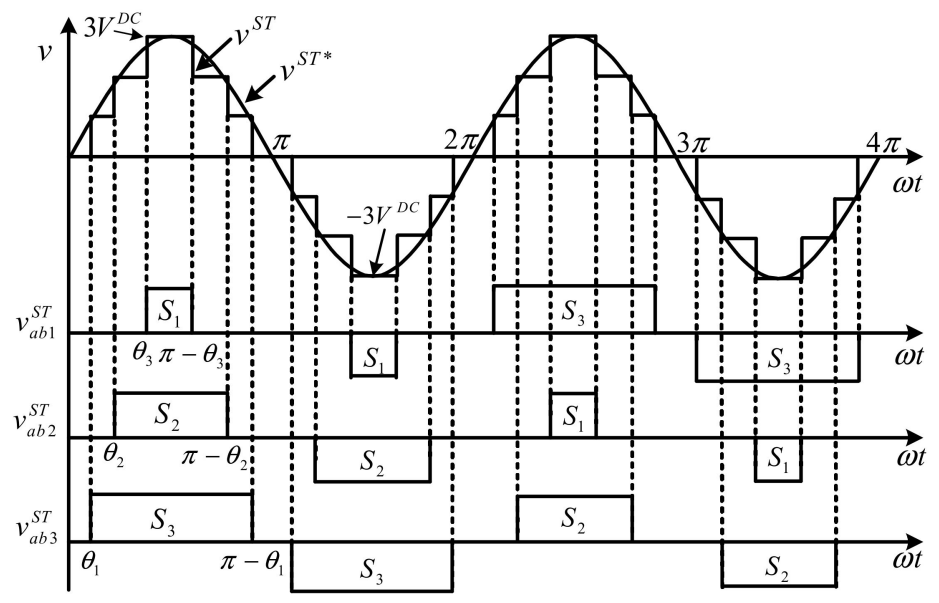

(b)

Figure 3. The proposed STATCOM controller and gating sequence (a) The STATCOM controller; (b) Alternate swapping of switching patterns for dc-link voltages balancing.

A fast powers detection method is needed for the real-time compensation scheme in Figure 3a. Figure 4 shows the fast active and reactive powers calculation block for the STATCOM controller by using the single-phase $\alpha-\beta$ reference frame method [34]. With the fast calculation method, the needed load powers for Equation (16) and the reactive power inputs of the three STATCOM arms are calculated in real-time. This accelerates the response of the STATCOM. 


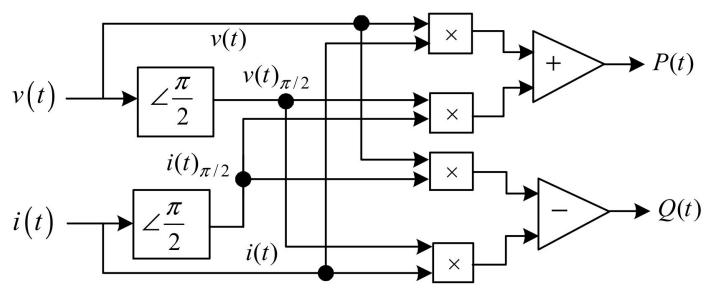

Figure 4. The fast power calculation block.

During the STATCOM operation, the switching signals $\theta_{1} \sim \theta_{3}$ for the three FHB cells in each STATCOM arm are swapped in each period of fundamental frequency, as shown in Figure $3 \mathrm{~b}$. The alternate swapping control of the switching signals can balance the dc-link voltages of FHB cells in each STATCOM arm without using additional dc voltage feedback control [35]. Furthermore, using step modulation in Figure $3 \mathrm{~b}$ significantly reduces switching losses, and the switching devices mainly have conducting loss. Therefore, the operation efficiency of the STATCOM main circuit can reach $99 \%$, which is much higher than other types of multilevel STATCOMs using high frequency switching techniques [36]. With the proposed controller in Figure 3, the STATCOM regulates reactive power inputs of its three arms independently for real-time load compensation.

\section{Simulation Results}

Figure 5 depicts the STATCOM simulation system constructed in the MatLab/Simulink program. The STATCOM main circuit is a transformerless, delta-connected configuration, as shown in Figure 1a. A single-phase load controlled by a switch creates unbalanced operation, which tests the transient and steady state compensation effects of the STATCOM. The sampling time of the STATCOM controller is set at $0.52 \mathrm{~ms}$, which is equivalent to 32 sampling points in a period of fundamental frequency $(60 \mathrm{~Hz})$. The parameters of the three PID controllers in Figure 3a are designed on-line using a sequential approach with three steps to optimize the system step response, starting with the proportional, integral and derivative gains set to zero: (1) Increase the proportional gain $K_{P}$ to get a stable response with a steady-state error; (2) Then, the integral gain $K_{I}$ is increased gradually for eliminating the steady-state error; (3) Finally, careful choice of the derivative gain $K_{D}$ improves the transient response performance. Another useful on-line designing approach for PID controller cab be seen in [37].

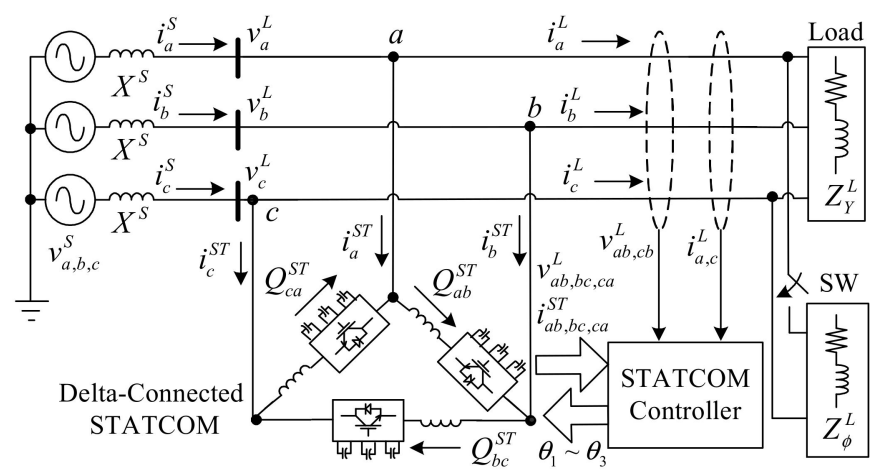

Figure 5. STATCOM simulation system.

Use of the assigned sampling time $(0.52 \mathrm{~ms})$ digitizes the parameters of the three analog PID controllers for the STATCOM in the simulation. Furthermore, the design results are also used as reference in the hardware implementation. The parameters selection of the two power components, the reactor $X^{S T}$ and the dc-link capacitor, significantly affects the transient response characteristics of the STATCOM. For example, decreasing the capacitance of the dc-link capacitor accelerates the 
response time of the STATCOM; however, this also amplifies the dc-link voltage ripple and increases the ac side harmonic current in steady-state operation. Reducing the inductance of the reactor $X^{S T}$ can also accelerate the response time, but the STATCOM control tends to be unstable. A trade-off procedure obtains the parameters of the two power components. In the paper, the capacitance is set at $3300 \mu \mathrm{F}$ and the inductance is selected as $5 \mathrm{mH}$, respectively. Appendix A lists the system parameters in Figure 5.

Figures 6-8 show the simulation results in detail. Figure 6a is the three-phase load current. At the beginning, the load current is balanced with lagging power factor. The switch is then closed to create unbalanced operation. With the STATCOM compensation, the source current is compensated to balance, as shown in Figure $6 \mathrm{~b}$. Figure $6 \mathrm{c}$ shows the phase- $a$ load voltage $v_{a}^{L}$ and the source current $i_{a}^{S}$. Figure $6 \mathrm{~b}, \mathrm{c}$ shows that source current is maintained in unity power factor after the change of load. Figure $6 \mathrm{~d}$ presents the synthesized STATCOM line current. By using the harmonics minimizing method in Equation (5), the synthesized line current contains little harmonics. In practical application, adequate filters should be employed to meet harmonics control standards.

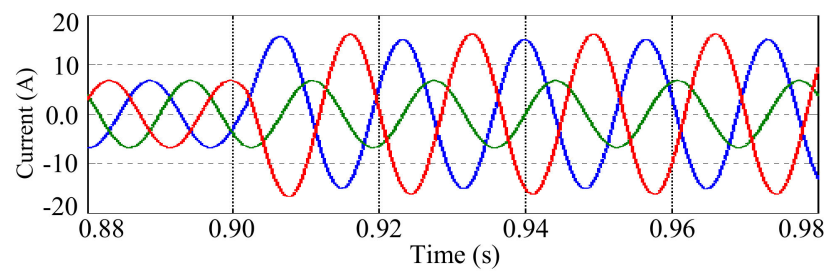

(a)

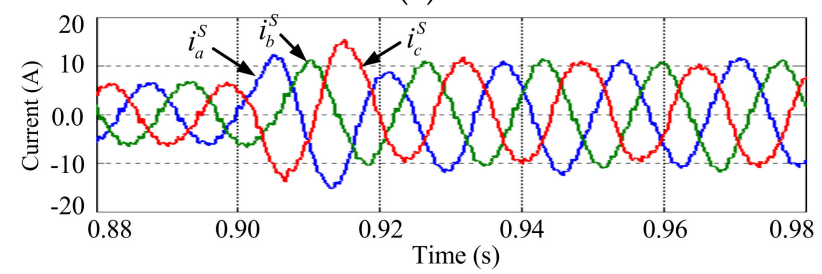

(b)

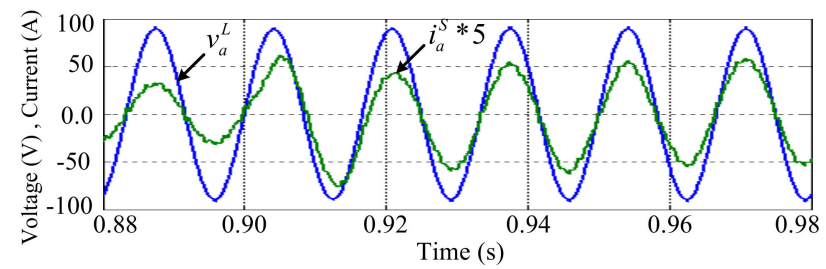

(c)

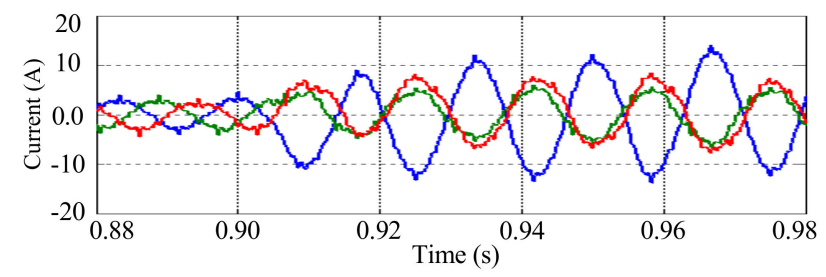

(d)

Figure 6. Compensation effect of STATCOM (a) Load current $\left(i_{a, b, c}^{L} ;(\mathbf{b})\right.$ Source current $\left(i_{a, b, c}^{S}\right)$; (c) Phase- $a$ load bus voltage and source current $\left(v_{a}^{L}, i_{a}^{S}\right)$; (d) STATCOM line current $\left(i_{a, b, c}^{S T}\right)$.

Figure $7 \mathrm{a}$ is the internal voltages response of the STATCOM. The STATCOM changes to unbalanced operation after the load change. It is observed in Figure $7 \mathrm{~b}$ that the three STATCOM arms produce harmonic current during the operation. Increasing the cascaded numbers of the FHB cells can significantly reduce the harmonic currents generated. Figure $7 \mathrm{c}$ shows the transient response of 
the current and voltage, $v_{a b}^{S T}$ and $i_{a b}^{S T}$, in the arm $a-b$ of the STATCOM. According to the compensation formula, the arm $a-b$ absorbs capacitive reactive power after the change of load. Similarly, the arms $b-c$ and $c-a$ absorb inductive and capacitive reactive powers at the same time, respectively. Figure $7 \mathrm{~d}$ illustrates the dc-link voltages responses of the STATCOM for reference.

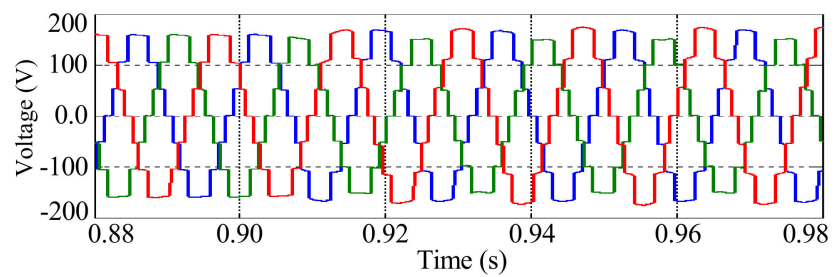

(a)

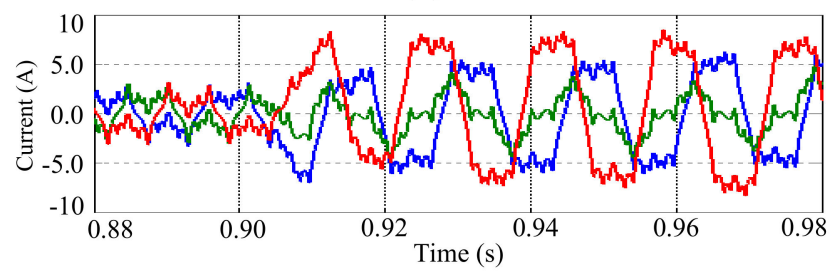

(b)

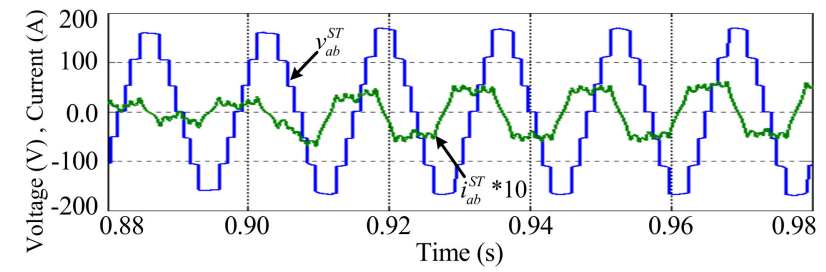

(c)

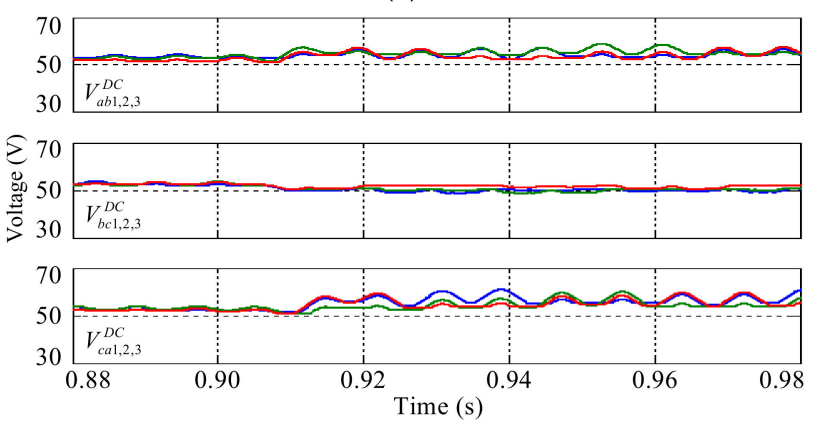

(d)

Figure 7. Compensation responses of STATCOM (a) STATCOM internal voltage $\left(v_{a b, b c, c a}^{S T} ;\right.$ (b) Each arm current $\left(i_{a b, b c, c a}^{S T}\right)$; (c) Arm $a-b$ voltage and current $\left(v_{a b}^{S T}, i_{a b}^{S T}\right)$; (d) Each arm dc-link voltages responses $\left(V_{a b 1,2,3}^{D C}, V_{b c 1,2,3}^{D C}, V_{c a 1,2,3}^{D C}\right)$.

Figure 8 shows the controller responses of the STATCOM in the simulation. Figure 8a presents the calculated compensation commands, $Q_{a b}^{S T *}, Q_{b c}^{S T *}$, and $Q_{c a}^{S T *}$, for each STATCOM arm. In Figure 8b, according to the commands, the STATCOM regulates its reactive power inputs, $Q_{a b}^{S T}, Q_{b c}^{S T}$, and $Q_{c a}^{S T}$. Figure $8 \mathrm{c}$ shows the dynamic responses of the internal angle commands, $\delta_{a b}^{S T *}, \delta_{b c}^{S T *}$, and $\delta_{c a}^{S T *}$. When the three arms' reactive power inputs reach their desired values, the three internal angle commands go back to near zero, independently. According to the internal angle commands, the active power inputs of the three STATCOM arms, $P_{a b}^{S T}, P_{b c}^{S T}$, and $P_{c a}^{S T}$, are responded independently, as shown in Figure $8 \mathrm{~d}$. The simulation results preliminarily confirm the function of the STATCOM for real-time load compensation. 


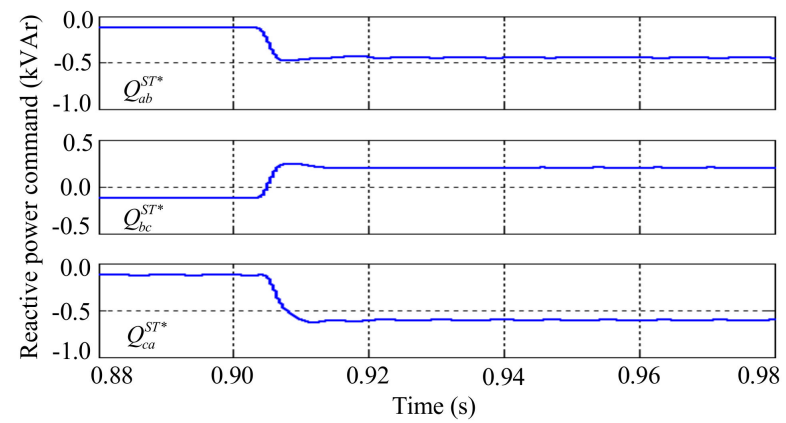

(a)

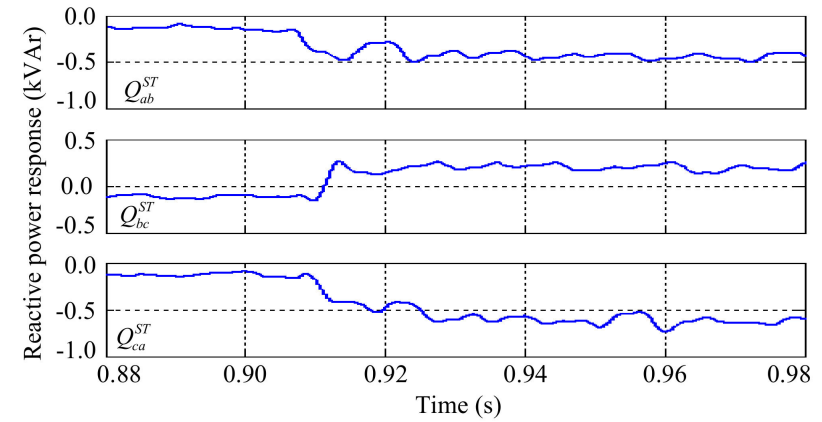

(b)

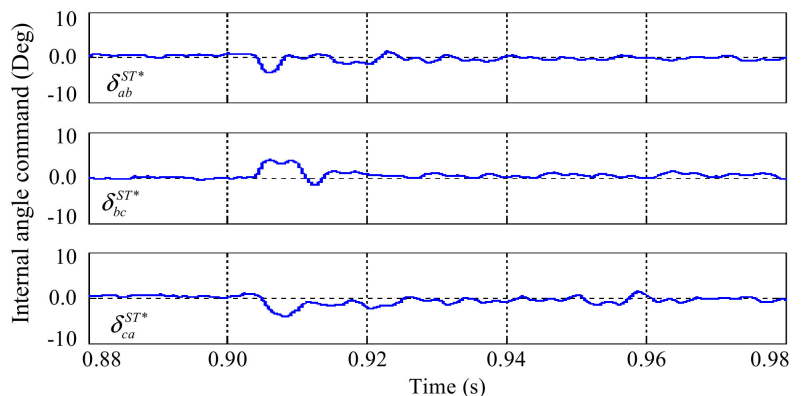

(c)

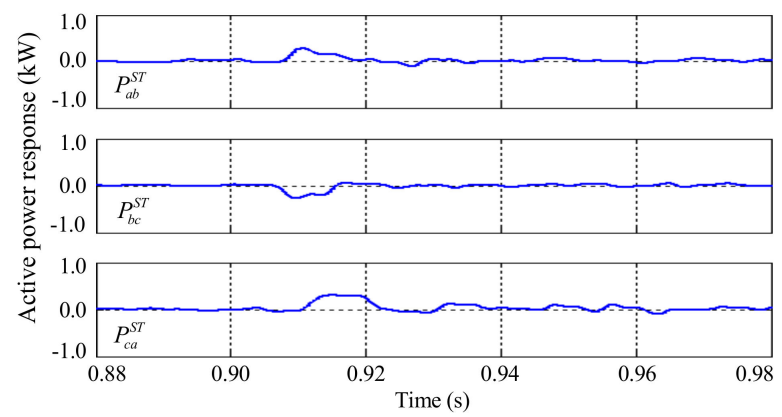

(d)

Figure 8. Controller responses of STATCOM (a) Each arm compensation command $\left(Q_{a b, b c, c a}^{S T *}\right.$; $(\mathbf{b})$ Each arm compensation response $\left(Q_{a b, b c, c a}^{S T}\right) ;(\mathbf{c})$ Each arm internal angle command $\left(\delta_{a b, b c, c a}^{S T *}\right) ;(\mathbf{d})$ Each arm active power response $\left(P_{a b, b c, c a}^{S T}\right)$.

Table 1 lists the three-phase source, load and STATCOM currents with the STATCOM compensation. The phase- $a$ is used as phase angle reference. Use of a current unbalance ratio, $I_{U R 2}(\%)=\left(I_{2} / I_{1}\right) \times 100 \%$, evaluates the compensation effect. The current unbalance ratio $I_{U R 2}^{L}(\%)$ of the load is $45.2 \%$. With the STATCOM compensation, the $I_{U R 2}^{S}(\%)$ of the source is improved to $0.7 \%$. At the same time, the power factor of the source is nearly compensated to unity. 
Table 1. Three-phase source, load and STATCOM currents after compensation.

\begin{tabular}{ccccccc}
\hline \multirow{2}{*}{ Source } & $I_{a}^{S}$ & $I_{b}^{S}$ & $I_{c}^{S}$ & $I_{1}^{S}$ & $I_{2}^{S}$ & $I_{\text {UR2 }}^{S}(\%)$ \\
\cline { 2 - 7 } & $7.32 \angle 0.15^{\circ}$ & $7.29 \angle-120.5^{\circ}$ & $7.23 \angle 120^{\circ}$ & 7.28 & 0.051 & $0.7 \%$ \\
\hline \multirow{2}{*}{ Load } & $I_{a}^{L}$ & $I_{b}^{L}$ & $I_{c}^{L}$ & $I_{1}^{L}$ & $I_{2}^{L}$ & $I_{\text {UR2 }}^{L}(\%)$ \\
& $10.67 \angle-52.3^{\circ}$ & $4.8 \angle-145.2^{\circ}$ & $11.48 \angle 103^{\circ}$ & 8.62 & 3.9 & $45.2^{\circ}$ \\
\hline \multirow{2}{*}{ STATCOM } & $I_{a b}^{S T}$ & $I_{b c}^{S T}$ & $I_{c a}^{S T}$ & $I_{a}^{S T}$ & $I_{b}^{S T}$ & $I_{c}^{S T}$ \\
& $4.12 \angle 119^{\circ}$ & $1.75 \angle-178^{\circ}$ & $5.61 \angle-119^{\circ}$ & $8.51 \angle 84.6^{\circ}$ & $3.54 \angle-86.2^{\circ}$ & $5.04 \angle-102^{\circ}$ \\
\hline \multicolumn{7}{c}{ Note: $I_{U R 2}(\%)=\left(I_{2} / I_{1}\right) \times 100 \%$, unit: Amp. }
\end{tabular}

Table 2 shows the harmonics analysis results of the three STATCOM arm currents and synthesized line currents in the simulation when the system goes to a steady-state operation. The 5 th and 7 th orders harmonic components are eliminated by using Equation (5). Other higher order harmonic components are limited by the reactors $X^{S T}$. The THDs of the source currents are within $6 \%$, and the THDs of the load bus voltages are within 1\%, which meet the IEEE-519 harmonic control standard [38]. Table 2 also shows that 3th order (zero sequence) harmonic currents circulate among the delta-connected main circuit. Due to te unbalanced operation of the STATCOM arms, circulating currents (zero sequence of triple order harmonic currents) do not completely circulate in the delta-connected main circuit loop. Unbalanced operation of the STATCOM generates different amount of 3th order harmonic current in each arm. Residual 3th order harmonic currents appear in the line currents. Increasing the numbers of the FHB cells in each STATCOM arm and incorporating the 3th order harmonic in the harmonic minimizing method can effectively solve this problem.

Table 2. Harmonics analysis of the STATCOM phases and synthesized lines currents.

\begin{tabular}{cccccccccc}
\hline \multicolumn{2}{c}{ Harmonic Orders } & 1st (A) & 3rd (A) & 5th (A) & 7th (A) & 9th (A) & 11th (A) & 13th (A) & THD (\%) \\
\hline \multirow{4}{*}{ Phases } & $I_{a b}^{S T}(n)$ & 3.79 & 0.88 & 0.01 & 0.03 & 0.36 & 0.09 & 0.07 & 26.27 \\
& $I_{b c}^{S T}(n)$ & 1.55 & 0.64 & 0.03 & 0.02 & 0.32 & 0.10 & 0.08 & 51.51 \\
& $I_{c c}^{S T}(n)$ & 4.96 & 1.03 & 0.06 & 0.03 & 0.31 & 0.11 & 0.06 & 23.19 \\
& $I_{a}^{S T}(n)$ & 7.57 & 0.16 & 0.06 & 0.07 & 0.05 & 0.17 & 0.11 & 4.94 \\
\hline \multirow{2}{*}{ Lines } & $I_{b}^{S T}(n)$ & 3.24 & 0.27 & 0.04 & 0.03 & 0.09 & 0.18 & 0.11 & 12.6 \\
& $I_{c}^{S T}(n)$ & 4.44 & 0.42 & 0.04 & 0.04 & 0.10 & 0.15 & 0.13 & 11.23 \\
\hline
\end{tabular}

\section{Hardware Test Results}

Figure 9 shows the hardware test system. Appendix B lists the parameters used in the hardware system. A Y-connected inductive load is connected in parallel with a single-phase load for testing. The STATCOM main circuit is a transformerless configuration with delta connection. Insulation gate bipolar transistor (IGBT) is used as switching elements in the STATCOM main circuit. The controller of the STATCOM is a TMS320F2812 DSP-based system, in which the sampling time is set at $0.52 \mathrm{~ms}$ to digitize the three PID controllers in the DSP. The real-time control program is firstly developed in the host PC and then downloaded to the DSP-based controller via a JTAG data link. Two eight-channel digital scopes are employed to measure the transient responses of the STATCOM.

Figures 10 and 11 present the experimental results. Figure 10 shows the current responses of the system with the STATCOM compensation. At the beginning of the test, the load is balanced with lagging power factor. Then, the close of the single-phase load creates an unbalanced operation, as shown in Figure 10a. The calculated unbalance ratio of the load current is $45 \%$. With the compensation of the STATCOM, the source current is corrected very quickly to nearly balanced, as shown in Figure $10 \mathrm{~b}$. The source current unbalance ratio is improved to $2 \%$. Figure $10 \mathrm{c}$ shows the phase- $a$ load bus voltage $v_{a}^{L}$ and the source current $i_{a}^{S}$, in which the source current is maintained in unity power factor after the load change. Figure 10d is the transient response of the synthesized STATCOM line current. Figure 11 shows other responses of the STATCOM for reference, which are quite agreed with the simulation results. A comparison between Figures $10 \mathrm{~d}$ and $11 \mathrm{~b}$ shows that uses of the 
harmonics minimizing method and the delta-connected STATCOM main circuit significantly eliminate the harmonic components generated in the three STATCOM arms. The compensation speed of the STATCOM is quite fast. Although the compensation formula used in the STATCOM is very simple, the compensation effect is satisfactory. The experimental results verify that the proposed STATCOM is suitable for real-time load balancing and power factor correction.

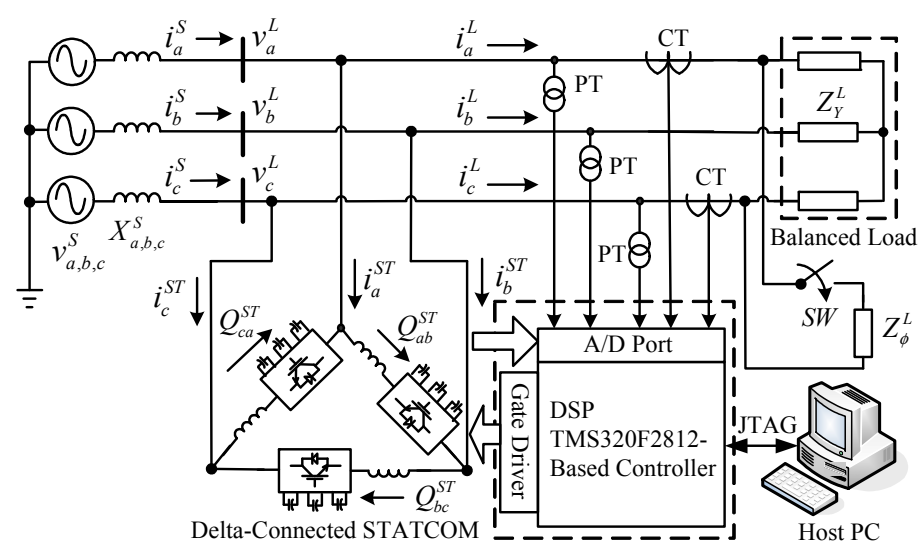

Figure 9. STATCOM hardware test system.

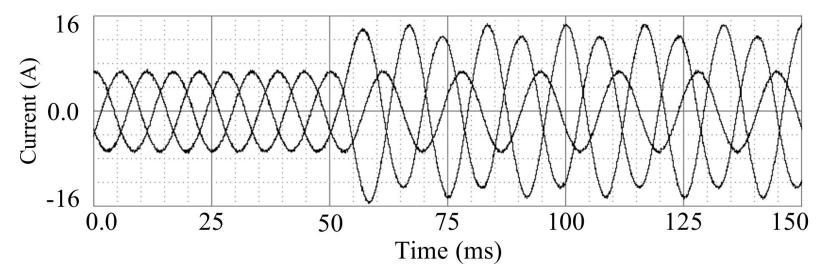

(a)

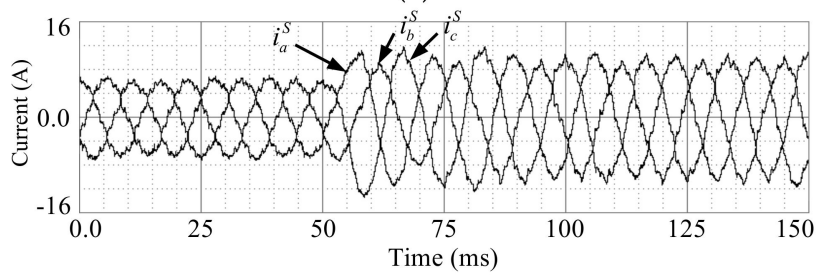

(b)

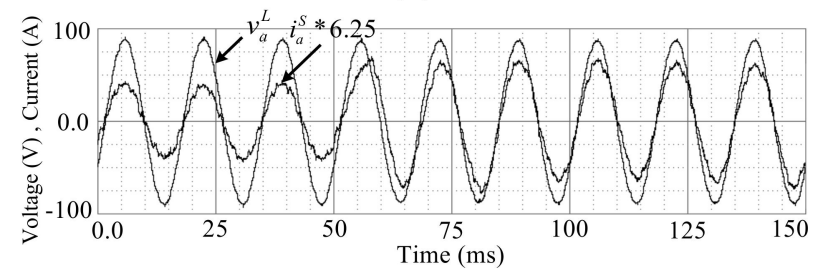

(c)

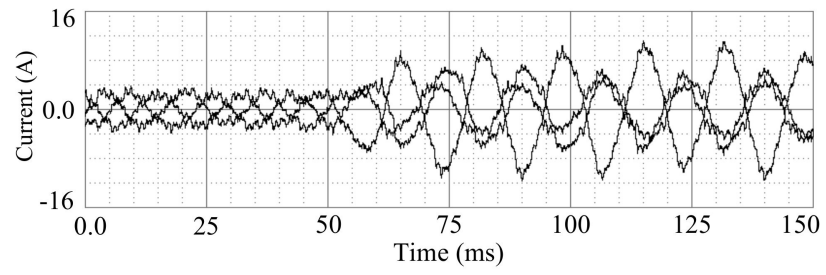

(d)

Figure 10. Transient responses with the STATCOM compensation (a) Load current $\left(i_{a, b, c}^{L} ;\right.$ (b) Source current $\left(i_{a, b, c}^{S}\right)$; (c) Phase- $a$ load bus voltage and source current $\left(v_{a}^{L}, i_{a}^{S}\right)$; (d) Line current of the $\operatorname{STATCOM}\left(i_{a, b, c}^{S T}\right)$. 


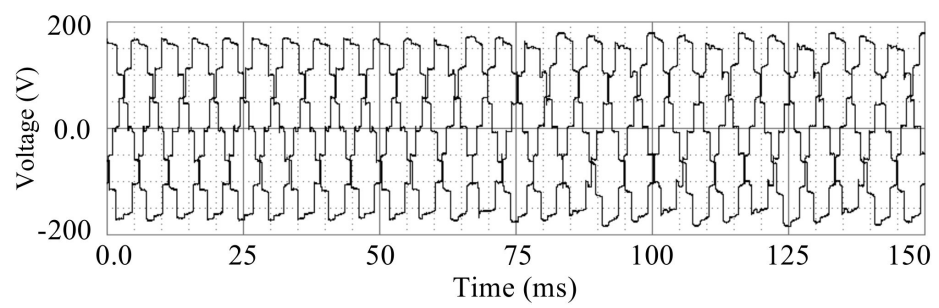

(a)

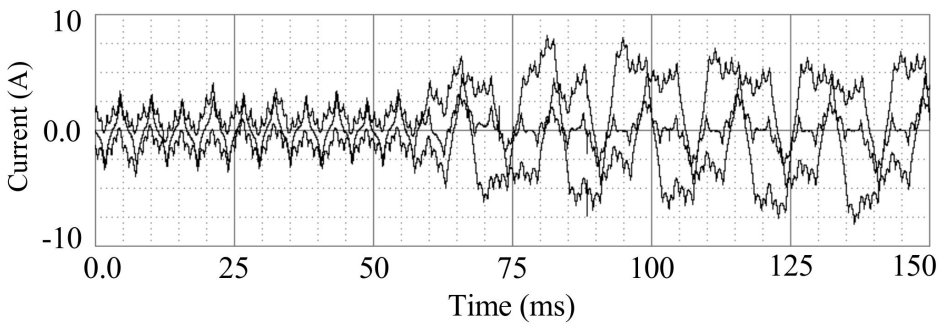

(b)

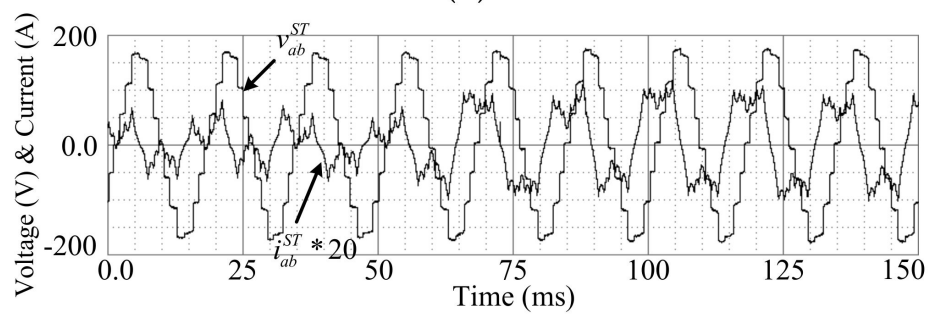

(c)

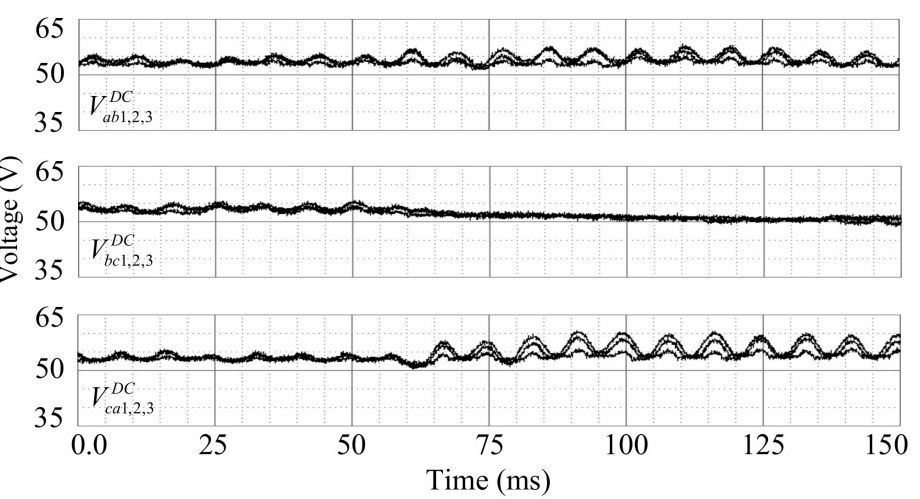

(d)

Figure 11. Transient responses of the STATCOM (a) Each arm internal voltage $\left(v_{a b, b c, c a}^{S T} ;\right.$ (b) Each arm current $\left(i_{a b, b c, c a}^{S T}\right)$; (c) Arm $a$ - $b$ voltage and current $\left(v_{a b}^{S T}, i_{a b}^{S T}\right)$; (d) Each arm dc-link voltages $\left(V_{a b 1,2,3}^{D C}, V_{b c 1,2,3}^{D C}, V_{c a 1,2,3}^{D C}\right)$.

The proposed phase angle control and step modulation scheme also shows a limitation in the STATCOM operation. Since the dc-link capacitor voltages need to be regulated frequently for different needs of reactive power compensations in the unbalanced load compensations. The charging and discharging of these dc-link capacitors need more time comparing to STATCOMs using high frequency PWM techniques. As a result, the response time of the proposed STATCOM is slower than STATCOMs using PWM controls. However, a high power-efficiency operation can be expected by using phase angle control and step modulation scheme for a STATCOM. In the planning stage of STATCOM, a trade-off between response time and power efficiency should be made. 


\section{Conclusions}

A delta-connected, transformerless STATCOM with cascade multilevel FHB converter for real-time unbalanced load compensation has been studied in the paper. A feedforward compensation formula derived by using the symmetrical components method in the phasor domain is proposed for the STATCOM. Both the computer simulation and experimental results show that the proposed STATCOM is very suitable for real-time load compensation. Although the harmonic components in the line current of the STATCOM are not so obvious in the paper, in practical applications, it should be eliminated properly to avoid polluting the power system. The PID controller dominates the transient response time of the STATCOM. Further study shows that use of other types of controller, such as adaptive controller based on dynamic STATCOM models, can improve the transient response time in load compensation. Additional functions of the STATCOM, such as voltage support and damping enhancement of system, can be implemented with properly tuned auxiliary controllers. This paper introduces a very suitable transition of technology from existing SVC to new-generation STATCOM in high power application.

Acknowledgments: The authors would like to thank the Ministry of Science and Technology, Taiwan for the financial support, project number MOST 104-2221-E-182-029. Valuable comments from the reviewers are also appreciated.

Author Contributions: Wei-Neng Chang conceived this article and designed the experiments; Ching-Huan Liao constructed the software simulation and performed the hardware experiment; all authors wrote the paper.

Conflicts of Interest: The authors declare no conflict of interest.

\section{Nomenclature}

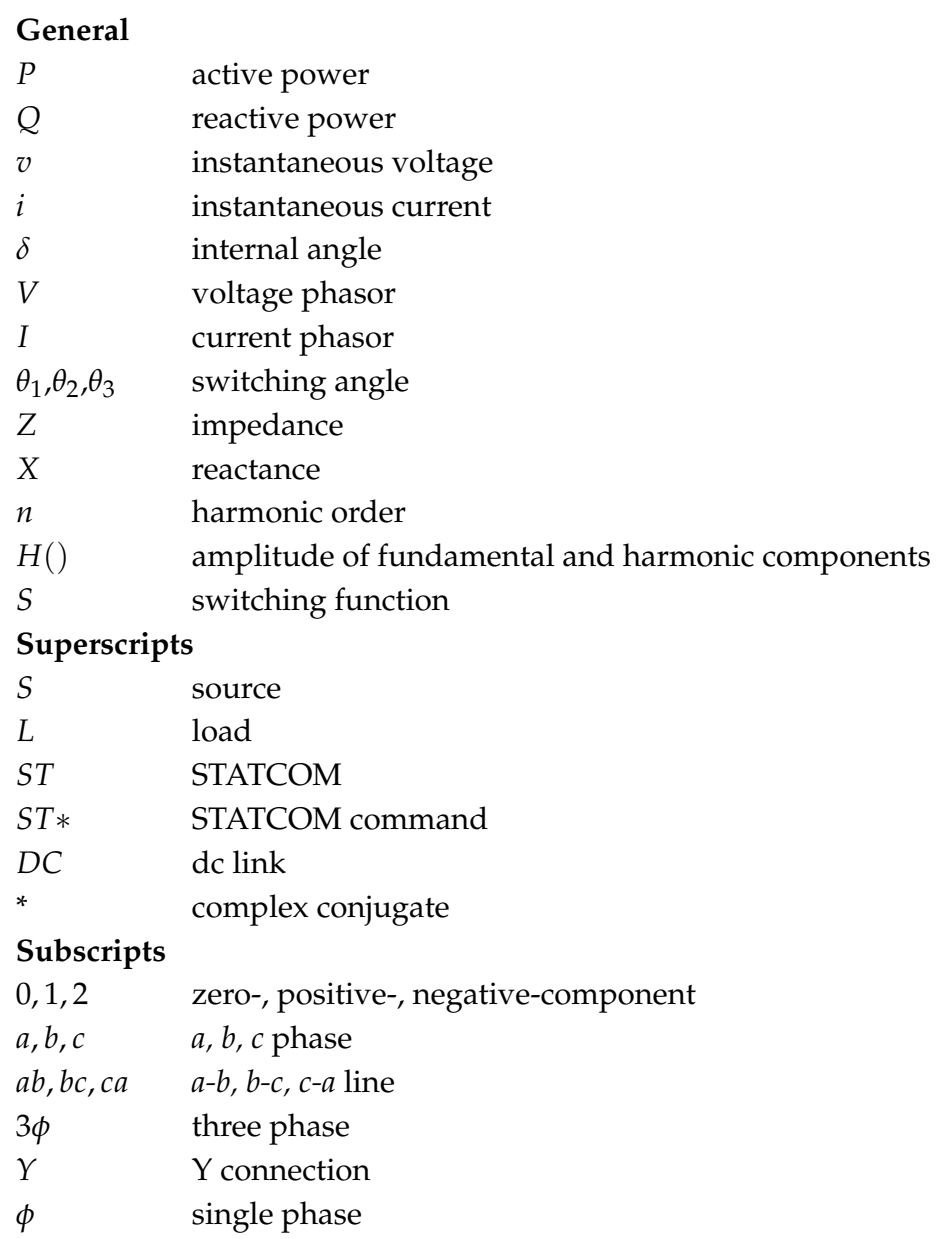




\section{Appendix A}

Simulation parameters:

System side:

$V_{l l}^{S}=110 \mathrm{~V}, f_{S}=60 \mathrm{~Hz}, X_{a, b, c}^{S}=0.005 \Omega, Z_{Y}^{L}=12+j 5.48 \Omega, Z_{\phi}^{L}=12.1+j 11.34 \Omega$.

STATCOM side:

$C_{a b, b c, c a}=3300 \mu \mathrm{F}, X_{a b, b c, c a}^{S T}=1.885 \Omega(5 \mathrm{mH} @ 60 \mathrm{~Hz}), K_{P}=0.475, K_{I}=0.0095, K_{D}=0.0011$,

$T_{\text {Samp }}=0.52 \mathrm{~ms}$ (for DSP), $\theta_{1}=11.68^{\circ}, \theta_{2}=31.18^{\circ}, \theta_{3}=58.58^{\circ}, \delta^{\operatorname{Max}}=+30^{\circ}, \delta^{\text {Min }}=-30^{\circ}$.

\section{Appendix B}

Hardware parameters:

System side:

$V_{l l}^{S}=110 \mathrm{~V}, f_{S}=60 \mathrm{~Hz}, Z_{Y}^{L}=12+j 5.48 \Omega, Z_{\phi}^{L}=12.1+j 11.34 \Omega$.

STATCOM side:

$C_{a b, b c, c a}=3300 \mu \mathrm{F}, X_{a b, b c, c a}^{S T}=1.885 \Omega(5 \mathrm{mH} @ 60 \mathrm{~Hz}), K_{P}=0.74, K_{I}=0.012, K_{D}=0.0013$,

$T_{\text {Samp }}=0.52 \mathrm{~ms}$ (for DSP), $\theta_{1}=11.68^{\circ}, \theta_{2}=31.18^{\circ}, \theta_{3}=58.58^{\circ}, \delta^{M a x}=+30^{\circ}, \delta^{M i n}=-30^{\circ}$.

\section{References}

1. Xu, Y.; Tolbert, L.M.; Kueck, J.D.; Rizy, D.T. Voltage and current unbalance compensation using a static var compensator. IET Power Electron. 2010, 3, 977-988. [CrossRef]

2. Miller, T.J.E. Reactive Power Control in Electric System; Wiley \& Sons: New York, NY, USA, 1982.

3. Gyugyi, L.; Otto, R.A.; Putman, T.H. Principles and applications of static, thyristor-controlled shunt compensators. IEEE Trans. Power Appar. Syst. 1978, 97, 1935-1945.

4. Chen, J.H.; Lee, W.J.; Chen, M.S. Using a static var compensator to balance a distribution system. IEEE Trans. Ind. Appl. 1999, 35, 298-304. [CrossRef]

5. Wang, J.; Fu, C.; Zhang, Y. SVC control system based on instantaneous reactive power theory and fuzzy PID. IEEE Trans. Ind. Electron. 2008, 55, 1658-1665. [CrossRef]

6. Czarnecki, L.S.; Hsu, S.M.; Chen, G. Adaptive balancing compensator. IEEE Trans. Power Deliv. 1995, 10, 1663-1669. [CrossRef]

7. Singh, B.; Saha, R.; Chandra, A.; Al-Haddad, K. Static synchronous compensators (STATCOM): A review. IET Power Electron. 2009, 2, 297-324. [CrossRef]

8. Ghosh, A.; Ledwich, G. Load compensating DSTATCOM in weak AC systems. IEEE Trans. Power Electron. 2003, 18, 1302-1309. [CrossRef]

9. Mishra, M.K.; Karthikeyan, K. A fast-acting DC-link voltage controller for three-phase DSTATCOM to compensate AC and DC loads. IEEE Trans. Power Electron. 2009, 24, 2291-2299. [CrossRef]

10. Atalik, T.; Deniz, M.; Koc, E.; Gercek, C.O.; Gultekin, B.; Ermis, M.; Cadirci, I. Multi-DSP and -FPGA-based fully digital control system for cascaded multilevel converters used in FACTS applications. IEEE Trans. Ind. Inform. 2012, 8, 511-527. [CrossRef]

11. Peng, F.Z.; Lai, J.S.; McKeever, J.W.; VanCoevering, J. A multilevel voltage-source inverter with separate DC sources for static VAr generation. IEEE Trans. Ind. Appl. 1996, 32, 1130-1138. [CrossRef]

12. Lai, J.S.; Peng, F.Z. Multilevel converters-a new breed of power converters. IEEE Trans. Ind. Appl. 1996, 32, 509-517.

13. Lee, C.K.; Leung, J.S.K.; Hui, S.Y.R.; Chung, H.S.H. Circuit-level comparison of STATCOM technologies. IEEE Trans. Power Electron. 2003, 18, 1084-1092. [CrossRef]

14. Rodriguez, J.; Lai, J.S.; Peng, F.Z. Multilevel inverters: A survey of topologies, controls, and applications. IEEE Trans. Ind. Electron. 2002, 49, 724-738. [CrossRef]

15. Peng, F.Z.; Lai, J.S. Dynamic performance and control of a static var generator using cascade multilevel inverters. IEEE Trans. Ind. Appl. 1997, 33, 748-755. [CrossRef]

16. Maharjan, L.; Inoue, S.; Akagi, H. A transformerless energy storage system based on a cascade multilevel PWM converter with star configuration. IEEE Trans. Ind. Appl. 2008, 44, 1621-1630. [CrossRef]

17. Sano, K.; Takasaki, M. A transformerless D-STATCOM based on a multivoltage cascade converter requiring no DC sources. IEEE Trans. Power Electron. 2012, 27, 2783-2795. [CrossRef] 
18. Gultekin, B.; Gercek, C.O.; Atalik, T.; Deniz, M.; Bicer, N.; Ermis, M.; Kose, K.N.; Ermis, C.; Koc, E.; Cadirci, I.; et al. Design and implementation of a 154-kV $\pm 50-$ Mvar transmission STATCOM based on 21-level cascaded multilevel converter. IEEE Trans. Ind. Appl. 2008, 48, 1030-1045. [CrossRef]

19. Gultekin, B.; Ermis, M. Cascaded multilevel converter-based transmission STATCOM: System design methodology and development of a $12 \mathrm{kV} \pm 12$ MVAr power stage. IEEE Trans. Power Electron. 2013, 28, 4930-4950. [CrossRef]

20. Akagi, H. Classification, terminology, and application of the modular multilevel cascade converter (MMCC). IEEE Trans. Power Electron. 2011, 26, 3119-3130. [CrossRef]

21. Peng, F.Z.; Wei, Q.; Dong, C. Recent advances in multilevel converter/inverter topologies and applications. In Proceedings of the 2010 International Power Electronics Conference, Sapporo, Japan, 21-24 June 2010; pp. 492-501.

22. Liu, Z.; Liu, B.; Duan, S.; Kang, Y. A novel DC capacitor voltage balance control method for casca1de multilevel STATCOM. IEEE Trans. Power Electron. 2012, 27, 14-27. [CrossRef]

23. Peng, F.Z.; Wang, J. A universal STATCOM with delta-connected cascade multilevel inverter. In Proceedings of the 2004 IEEE 35th Annual Power Electronics Specialists Conference, Aachen, Germany, 20-25 June 2004; Volume 5, pp. 3529-3533.

24. Chang, W.N.; Liao, C.H. Real-time load compensation by using a cascaded multilevel inverter-based STATCOM. In Proceedings of the 2011 IEEE Ninth International Conference on Power Electronics and Drive Systems, Singapore, 5-8 December 2011; pp. 840-846.

25. Chang, W.N.; Liao, C.H.; Wang, P.L. Unbalanced load compensation in three-phase power system with a current-regulated DSTATCOM based on cascade modular h-bridge converter. J. Mar. Sci. Technol. 2016, 24, 484-492.

26. Song, Q.; Liu, W.; Yuan, Z. Multilevel optimal modulation and dynamic control strategies for STATCOMs using cascaded multilevel inverters. IEEE Trans. Power Electron. 2007, 22, 1937-1946. [CrossRef]

27. Shi, Y.; Liu, B.; Duan, S. Eliminating DC current injection in current-transformer-sensed STATCOMs. IEEE Trans. Power Electron. 2013, 28, 3760-3767. [CrossRef]

28. Hagiwara, M.; Maeda, R.; Akagi, H. Negative-sequence reactive-power control by a PWM STATCOM based on a modular multilevel cascade converter (MMCC-SDBC). IEEE Trans. Ind. Appl. 2012, 48, 720-729. [CrossRef]

29. Du, S.; Liu, J.; Lin, J.; He, Y. A novel DC voltage control method for STATCOM based on hybrid multilevel h-bridge converter. IEEE Trans. Power Electron. 2013, 28, 101-111. [CrossRef]

30. Wu, P.H.; Chen, H.C.; Chang, Y.T.; Cheng, P.T. Delta-connected cascaded H-bridge converter application in unbalanced load compensation. IEEE Trans. Ind. Appl. 2017, 53, 1254-1262. [CrossRef]

31. Schauder, C.; Menhta, H. Vector analysis and control of advanced static VAR compensators. IEE Proc. C Gener. Transm. Distrib. 1993, 140, 299-306. [CrossRef]

32. Sirisukprasert, S.; Lai, J.S.; Liu, T.H. Optimum harmonic reduction with a wide range of modulation indexes for multilevel converters. IEEE Trans. Ind. Electron. 2002, 49, 875-881. [CrossRef]

33. Liu, Y.; Hong, H.; Huang, A.Q. Real-time calculation of switching angles minimizing THD for multilevel inverters with step modulation. IEEE Trans. Ind. Electron. 2009, 56, 285-293. [CrossRef]

34. Chang, W.N.; Pon, W.H.; Yeh, K.D. Digital design and implementation of fast power data detector. In Proceedings of the IEEE International Conference of Power Electronics and Drive Systems (PEDS'2001), Denpasar, Indonesia, 25-25 October 2001; Volume 200, pp. 623-627.

35. Peng, F.Z.; McKeever, J.W.; Adams, D.J. A power line conditioner using cascade multilevel inverters for distribution systems. IEEE Trans. Ind. Appl. 1998, 34, 1293-1298. [CrossRef]

36. Tolbert, L.M.; Peng, F.Z.; Habetler, T.G. Multilevel converters for large electric drives. IEEE Trans. Ind. Appl. 1999, 35, 36-44. [CrossRef]

37. Rashid, M.H. Power Electronics Handbook: Devices, Circuits, and Applications, 3rd ed.; Elsevier Inc.: Oxford, UK, 2011; p. 1049.

38. IEEE Recommended Practices and Requirements for Harmonic Control in Electrical Power Systems; IEEE Std. 519-1992; IEEE: New York, NY, USA, 1993.

(C) 2017 by the authors. Licensee MDPI, Basel, Switzerland. This article is an open access article distributed under the terms and conditions of the Creative Commons Attribution (CC BY) license (http:/ / creativecommons.org/licenses/by/4.0/). 